\title{
ENTRE SÍSIFO E CHRONOS: uma reflexão sobre tempos da docência, da infância e da esperança
}

\author{
Aline Praça Bernar, \\ Fabiana Eckhardt, \\ Renato Simões Moreira
}

Resumo

Sísifo, figura da mitologia grega, evoca-nos duas distintas ideias: a sagacidade que ludibria os poderosos por duas vezes enganou as forças do submundo e escapou à morte - e o sofrimento de um esforço que jamais finda. Condenado a uma pena exemplar por enganar as forças do inferno, Sísifo é submetido a um ordálio cíclico e sem fim. Contudo, fica uma questão: Teria a atuação docente, principalmente durante o isolamento social e suas aulas remotas, seu quê de pena sisífica? Ou existe no aparente castigo do filho de Éolo mais que as aparências sugerem? O presente artigo apresenta uma aproximação entre o mito de Sísifo e o fazer docente voltado ao atendimento às classes populares, revelando um drama sob a ótica do esperançar freireano, sob os auditores de diferentes dimensões do tempo: Chronos, Aión e Kairós. Tal drama surge no tempo aiônico, o tempo da infância, no tempo do fazer sempre de novo sem deixar pesar em vão o fardo da pedra. Pedra esta ressignificada no presente texto, repensada como um fazer sempre novo, mesmo que aparentemente repetitivo. Aludimos ao esforço sísifo de carregar a mesma pedra morro acima a prática docente pautada no ensinar e aprender que se confundem e se complementam em uma espera esperançosa e utópica imbricada no inconformismo e na fé da emancipação social.

Palavras-chave: tempo de espera; tempo de esperança; docência na pandemia.

BETWEEN SISIPHUS AND CHRONOS: a reflection on time of teaching, childhood and hope

\begin{abstract}
Sisyphus, a figure from greek mythology, evokes two distinct ideas: the wit that deceives the powerful twice deceived the molds of the underworld and escaped death - and the suffering of an effort that never ends. Sentenced to an exemplary penalty for deceiving the forces of hell, Sisyphus is subjected to a cyclic and endless ordeal. However, a question remains: Would the teaching activity, especially during social isolation and its remote classes, have its kind of sisyphean penalty? Or is there in the apparent punishment of Aeolus's son more than appearances obtained? This article presents an approximation between the myth of Sisyphus and the teaching practice aimed at serving the popular classes, revealing a drama from the perspective of the freirean hope, under auditors from different dimensions of time: Chronos, Aión and Kairós. Such drama arises in the aionic time, the time of childhood, in the time of doing it over and over again without letting the stone's burden weigh in vain. Stone is re-signified in this text, rethought as a way of always new, even if apparently repetitive. We allude to the sisyphus effort to carry the same stone up the hill, the teaching practice based on not using and learning to be confused and complemented in a hopeful and utopian waiting imbricated in non-conformity and in the faith of social emancipation.
\end{abstract}

Keywords: waiting time; time of hope; teaching in the pandemic. 
DOI: $10.12957 /$ teias.2021.62392

ENTRE SISIPHUS Y CHRONOS: una reflexión sobre tiempos de enseñanza, infancia y esperanza

Resumen

Sísifo, una figura de la mitología griega, evoca dos ideas distintas: el ingenio que engaña a los poderosos engañó dos veces a las fuerzas del inframundo y escapó de la muerte - y el sufrimiento de un esfuerzo que nunca termina. Condenado a una pena ejemplar por engañar a las fuerzas del infierno, Sísifo es sometido a una prueba cíclica e interminable. Sin embargo, queda una pregunta: ¿La actividad docente, especialmente durante el aislamiento social y sus clases remotas, tendría una especie de penalización sísifo? ¿O hay en el aparente castigo del hijo de Eolo más de lo que sugieren las apariencias? Este artículo presenta una aproximación entre el mito de Sísifo y la práctica docente orientada al servicio de las clases populares, revelando un drama desde la perspectiva de la esperanza freireana, bajo auditores de diferentes dimensiones del tiempo: Chronos, Aión y Kairós. Tal drama surge en el tiempo aiónico, el tiempo de la niñez, en el momento de hacerlo una y otra vez sin dejar que la carga de la piedra pese en vano. La piedra se vuelve a significar en este texto, repensada como una forma de siempre nuevo, aunque aparentemente repetitivo. Aludimos al esfuerzo de sísifo por llevar la misma piedra cuesta arriba a la práctica docente basada en la enseñanza y el aprendizaje que se funden y complementan en una espera esperanzada y utópica imbricada en el inconformismo y la fe en la emancipación social.

Palabras clave: tiempo de espera; tiempo de esperanza; enseñar en la pandemia.

\section{INTRODUÇÃO}

\section{Este fardo invisible que transportamos, es semejante al de Sísifo: logramos llevar la roca arriba, un poco más cada día cuando de pronto algo surge y nos retrocede.} Mário Rivero

Subindo as encostas do Tártaro, Sísifo rola sua imensa pedra morro acima, até que, banhado de suor e com as mãos em chagas, suas forças lhe faltam e seu fardo rola por todo o caminho abaixo. Ele precisa então retomar, trôpego, seu exaustivo trabalho, num ciclo infinito de subidas e descidas. O drama de Sísifo vem sendo tomado ao longo da história da humanidade para ilustrar momentos como o que vivemos. Um momento que podemos definir como absurdo, contraditório, despropositado, insensato, marcado por evidentes retrocessos no campo das conquistas sociais das classes populares: para terem empregos, os/as trabalhadores/as precisam abrir mão de seus direitos, pois esses mesmos direitos "impediriam" o crescimento econômico; estudantes com necessidades especiais não deveriam estar em classes regulares, pois atrapalhariam sua turma; cotas são questionadas, pois seriam "injustas". Tantas conquistas que tínhamos como bem sedimentadas evolam-se como fumaça, cumprindo a velha profecia de Marx: "Tudo o que era sólido se desmancha no ar". Ou, talvez, com certa dose de otimismo, um momento em que, entre tão terríveis absurdos, as esperanças necessariamente se renovem, mas na acepção freireana do termo, pois, assim como Sísifo empurra sua pedra com o melhor de suas forças, agindo não só como um homem condenado a uma tarefa sem fim — afinal, era prisioneiro no Tártaro —, mas também como alguém que, intimamente, espera concluir seu trabalho (triste ironia das punições impostas pelos deuses, que são mais cruéis quando nos trazem alguma esperança de cumprimento da sentença, ainda que objetivamente não haja), estamos nós, professores/as "empurrando" mais um ano ou período letivo morro acima. Enquanto a pandemia não acaba, seguimos desenvolvendo o 
nosso trabalho sob o som de vozes que afirmam que a escola não será mais a mesma. As mesmas vozes que ordinariamente vaticinam os fatalismos neoliberais, afirmando que fora da lógica de mercado e dos ditames do capital "não há salvação".

Porém, assim como o exaurido Sísifo, durante o percurso vamos percebendo que o esforço necessário para chegar ao topo se mostra hercúleo, maior do que a possibilidade que nos permitem nossos corpos combalidos e mentes cansadas. Da mesma forma, parece-nos que "isolados/as" em nossas casas, limitando nossos encontros com colegas e estudantes à mediação de telas, ou aferrados ao cumprimento de tarefas pensadas por uns poucos, para que muitos as executem, sentimos que nossas forças vacilam e a pedra pode nos escapar, como nos convida a pensar Mário Rivero na epígrafe. Quem sabe, soluções mais criativas nos permitissem, no limiar dessas situaçõeslimite, a insurgência de "inéditos viáveis" para escapar ao esforço sisífico, ou melhor: para enchêlo de significado e sentido.

A ideia de isolamento, aqui, não questiona o afastamento social das pessoas como tentativa de conter a disseminação do coronavírus SARS-COV-2. O isolamento a que nos referimos diz respeito às práticas individualistas nas quais vamos nos inserindo - as relações escolares, verticalmente hierarquizadas, entre os que planejam e os que executam, encontrou no modelo remoto decorrente do isolamento social a tempestade perfeita para se manifestar com ares de novidade. Entre professores/as palestrando solitariamente e câmeras de vídeo fechadas que exibem apenas o ícone do que deveria ser um estudante, a tecnologia criada para aproximar as pessoas serve de mediação para práticas de ensino sem aprendizagem e cumprimentos de tarefas quase que apenas gameficadas, efetivas o suficiente para garantir uma participação discente meramente formal. Um contato sem encontro. Muitas falas sem diálogo. Sísifo segue só, morro acima, e seus braços começam a vacilar...

Neste texto, pretendemos uma aproximação entre o trabalho aparentemente vão de Sísifo, ao empurrar sua pedra, e o dos/as professores/as que podemos ser, remotamente, durante a pandemia. Mas não só. Desejamos esboçar uma reflexão pautada nos ensinamentos de Paulo Freire e, a partir deles, perceber insurgência de táticas (CERTEAU, 2012) possíveis no limiar de situaçõeslimite, alicerçadas no esperançar como motor do desenvolvimento do trabalho docente, compreendendo também o tempo da docência como o tempo da infância e da esperança. Afinal, assim como nós, adultos e crianças, o que é o trabalho de nossa humana docência senão uma tarefa cotidianamente inconclusa? Assim como Sísifo, executamos a tarefa de ensinar e aprender e/ou aprender e ensinar esperançando, sem esperar por um final.

\section{A PEDRA, A PANDEMIA E O TRABALHO DOCENTE: TEMPOS DE ESPERA, TEMPOS DE ESPERANÇAR}

\section{Tempo Rei! Ó Tempo Rei! Ó Tempo Rei! Transformai as velhas formas do viver... Gilberto Gil}

O tempo, mecanismo de nosso cérebro já muito discutido pela filosofia, continua a nos encantar. É o tempo, que para ser melhor compreendido, é separado em sua dimensão quantitativa e qualitativa: pode ser Chronos — segundo Kohan (2007), a palavra mais conhecida para se referir ao tempo contabilizado em horas e minutos —; pode ser Kairós — que significa medida, proporção, mas também oportunidade. No entanto, o tempo pode ser ainda Aión, cuja dimensão nos apresenta uma outra lógica temporal, a da força infantil, não necessariamente cronológica, própria do jeito de ser criança. Chronos, Kairós e Aión nos oferecem impressões distintas de compreensão do 
DOI: $10.12957 /$ teias.2021.62392

tempo. Por outro lado, as vozes que nos sussurram aos ouvidos indicam as inevitáveis mudanças da escola, num período pós-pandêmico - que, assim como as promessas do futuro moderno, só se faz presente em sua ausência -, teimosamente apegam-se a Chronos como o único tempo viável.

Urge que aprendizagem e ensino se conformem aos sessenta entalhes do pequeno ditador, porque - ironicamente! - "não há tempo" para Kairós e Aión. Estes pertencem aos sonhadores e não têm espaço na ordem estabelecida pela educação bancária preconizada pelos/as empresários/as da educação. Talvez, assim seja melhor: Aión e Kairós ficam circunscritos à dimensão de nossa zona de autonomia relativa - o pequeno jardim que cultivamos "entre o limite externo e o limite interno" impostos à nossa prática em função de nossas atribuições (VASCONCELOS, 2014, p. 48) -, guardando-nos do faminto Chronos, pronto a nos devorar, como fizera a seus filhos, em nome das demandas da educação burguesa de resultados. Com isso, o tempo da espera - cronológico, conformado à quantidade de movimentos dos ponteiros - parece ter também duração distinta do tempo do esperançar - este, pertencente a Aión e Kairós, tempos outros, da qualidade do viver.

Acreditamos que o momento em que estamos vivemos pode ser compreendido por pelo menos duas dimensões temporais: $\mathrm{O}$ tempo da espera - marcado principalmente pelo aguardo do fim da quarentena, da pandemia, somado à fé na eficácia das vacinas e ao que encontraremos quando retornarmos ao nosso conhecido "mundo real" - como se, com o impedimento de vivermos a vida como costumávamos, ela estivesse suspensa -, e o tempo do esperançar - o tempo aiônico por natureza - que não se deixa medir pela sucessão dos fatos nem pelos ponteiros do relógio. É o tempo da infância por excelência, segundo Kohan. É o tempo no qual nós, professores/as, carregamos nossas pedras cotidianas até o cume do morro. Tempo que divide seu lugar com o sonho e a utopia, aos moldes de Freire.

Estaríamos vivendo uma suspensão temporal? Não. Os dias, meses e anos estão passando. Chronos segue, faminto, seu festim costumeiro. Estamos nos tornando outros e outras, enquanto empurramos a pedra - avolumada hoje pela pandemia - colina acima. Porém, o cansaço causado pelo esforço físico somado à preocupação de não deixá-la escapar, nos esgota física e mentalmente. Olhamos para o lado, e sem encontrar outras mãos para substituir as nossas quando já estão encharcadas de suor ou machucadas, é o desespero que surge - hoje, nomeado por um estrangeirismo pomposo que dá ares de novidade, "Burnout". A Síndrome de Burnout nos parece ser o drama de Sísifo redivivo, "repaginado" para o século XXI. Assim, vemos o tempo da espera como o tempo do desespero - Chronos devorando nossas esperanças. Segundo Freire (2001) não há como sequer começar a pensar a educação sem esperança. Percebemos, portanto, que esse tempo da espera que vivemos hoje é o tempo neoliberal. É o caminhar inexorável em direção aos fatalismos. Parece que ouvimos todos os dias: "Não há alternativa. O sonho acabou". A metáfora da pedra une, contudo, nessa dimensão, Sísifo e Chronos, o titã. A pedra daquele é o ordálio que oprime e imobiliza - a mãe que se desdobra entre seus afazeres domésticos e trabalhos como diarista está também rolando a pedra morro acima -; a pedra deste é a tática que engana o forte Chronos devora uma pedra enrolada em cueiros, sendo enganado por Reia ${ }^{1}$, sua mulher, que conseguiu salvar seu filho mais novo, Zeus, que destronaria seu pai. A tática do mais fraco burlou a estratégia do forte, como lemos em Certeau, e lançou sementes que germinariam no futuro.

Isolados socialmente, por conta da pandemia, estamos ainda mais subjugados ao papel de marionetes das estratégias e manipulações das relações de poder; nossas possibilidades de ações e de "fazer com" encontram-se permeadas (vigiadas?) por empresas e sistemas tecnológicos que

\footnotetext{
${ }^{1}$ Chronos devorava seus filhos porque fora profetizado que um deles usurparia seu trono, assim como ele usurpara a coroa de Urano. Orientada por Gaia, Reia salva Zeus, com o ardil da pedra.
}

Revista Teias v. 22 • n. 67 • out./dez. 2021 • Seção temática Celebrar Paula Freire: reencantar o mundo e as utopias 
DOI: $10.12957 /$ teias.2021.62392

expressam nas entrelinhas a busca incessante pelo lucro e a vontade de nos afastar cada vez mais do papel que nos cabe como docentes, indo contra o caminho desenhado por Freire em várias obras, uma vez que precisamos uns/umas dos/as outros/as, já que acreditamos que a aquisição do conhecimento, a emancipação e a autonomia só se dão em comunhão.

Assim como Sísifo, à luz do que nos explica Certeau (2012), seguimos com nossas práticas teimosas, astuciosas e cotidianas na luta e na busca do que ele chama de tática.

A tática não tem por lugar senão o do outro. E por isso deve jogar com o terreno que lhe é imposto tal como o organiza a lei de uma força estranha. Não tem meios para se manter em si mesma, à distância, numa posição recuada, de previsão e de convocação própria: a tática é o movimento 'dentro do campo de visão do inimigo’, como dizia von Bullow’ (CERTEAU, 2012, p. 94)

Dentro do campo de visão do inimigo, da manutenção do status quo, vamos seguindo e trabalhando com as questões que podemos. Entretanto, vamos também tendo que lidar com sentimentos imprevisíveis, nossos e dos outros. São sentimentos que nos provocam a refletir e a agir, mesmo com a docilidade exigida, sob e com os "azares do tempo". De olho nas brechas e oportunidades, agimos com a astúcia possível ao fraco; talvez esse seja nosso "último recurso": raptar dos fortes, sob os augúrios de Kairós, pequenas, mas significativas vitórias.

O desespero parece se convidar a estar ao lado da esperança - a pedra que oprime Sísifo e a pedra que engana Chronos - "A tática que vale pela pertinência que dá ao tempo" (ibidem, p. 96). A mesma pedra ressignificada é, pois, o tempo do esperançar que nos provoca a começar sempre de novo, cada vez que descuidamos ou perdemos as forças e deixamos a pedra rolar e voltar à base da montanha. O tempo do esperançar é o tempo das utopias, de constituição da história, o tempo inacabado e incompleto, e por isso, o tempo da mudança. É Aión, o tempo da incansável infância, e Kairós, o tempo da oportunidade. Diferente do tempo da espera - tempo de Chronos -, que é o tempo dado, acabado, sem alteração, tempo da dominação, porque já foi definido por outrem para nós e, por isso, é fardo - como a pedra de Sísifo. "As táticas apontam para uma hábil utilização do tempo", nos diz mais uma vez Certeau. É o tempo da certeza - o implacável Chronos - que nos diz tão convictamente que, após a pandemia, nada será como antes, o que vai prevalecer na escola é o ensino híbrido, ou outra novidade tecnocrática de mesma natureza, cuja função é garantir os ganhos dos/as empresários/as da educação. Esta, não mais relacionada ao tempo de formação, exercício de nossa vocação ontológica para ser mais; é, agora, "produto", franquia desta ou daquela marca, cuja função é garantir vantagens estratégicas no renhido combate a que se resume a sociedade capitalista. Pedra, também, mas entalhada, para "agregar valor de mercado".

Voltando o olhar para o ano de 2019, o que havia na escola antes da pandemia, senão um Sísifo empurrando sua pedra? Professores/as e estudantes atarefados com o cumprimento de programas exógenos e segmentados, que desrespeitam o ritmo de aprendizagem individual marcado por Aión e Kairós - na busca de uma pretensa homogeneidade; avaliações de larga escala que deveriam se voltar para sistemas educativos, mas têm sua finalidade pervertida e tornam-se instrumentos de culpabilização para docentes e sentença de incapacidade para discentes; enfim, os sujeitos populares da educação pública lidando com um cobertor sempre curto demais. Rolando a pedra morro acima nos degladiamos com opções em que as perdas saltam aos olhos: cumprir o programa e aceitar que é "assim mesmo, que nem todos aprendem", ou relegar o cumprimento do programa a segundo plano e ser penalizado/a por isso; reprovar massivamente estudantes "que não aprendem" ou promover todos/as, esses/as estudantes, mesmo que não aprendam. As forças vacilam, a pedra rola morro abaixo: os/as professores/as titubeiam, duvidam de suas potências, 
DOI: $10.12957 /$ teias.2021.62392

perdem seu propósito; os/as estudantes acabam se "evadindo" - eufemismo tão corretamente criticado por Freire (2020), para indicar expulsão tardia -, após frustrantes reprovações. A consciência permanece intransitiva (FREIRE, 2011b) ${ }^{2}$, presa às exigências impostas pelo capital à educação - a ênfase no cumprimento acrítico do currículo e a luta por alcançar os índices preconizados para a escola, do lado dos/as educadores/as, e a corrida para obter pontos para a promoção, do lado dos/as educandos/as, de modo a conseguir os certificados e diplomas que tornarão menos árdua a luta por boas oportunidades, numa sociedade em que elas são escassas e ferrenhamente disputadas. Dos dois lados, o cansaço por desempenhar performances extenuantes para perseguir metas cada vez mais difíceis de se alcançar, e cada vez menos recompensadoras, quando alcançadas. Uma escola de gente cansada: Sísifos exauridos por todos os lados; "a arte da guerra cotidiana", como diz Certeau (2012).

Entretanto, a escola não é só feita do tempo de espera. A escola viva, constituída por pessoas que se encontram e dialogam, é também educadora da esperança, mescla do entusiasmo aiônico e da prontidão de Kairós. Afinal, é a esperança uma necessidade ontológica, um imperativo existencial (FREIRE, 2008), e na compreensão de que somos sujeitos históricos, agentes da mudança, vamos nos formando no tempo do esperançar. Na apresentação do livro Pedagogia da Indignação, Ana Maria de Araújo Freire nos diz que a esperança é a "matriz da dialeticidade entre ela mesma, a raiva ou indignação e o amor" (FREIRE, 2000, p. 13). É porque amamos o mundo que nos indignamos e sentimos raiva da injustiça, da desigualdade, mas certos da nossa presença, vivemos praticando o esperançar, como tempo do fazer acontecer, na luta pela concretização de nossos "sonhos possíveis". E o desejo maior que nos move é que a "nuvem acinzentada", que segundo Freire (2000) é a ideologia fatalista presente no discurso neoliberal, não aniquile nosso sonho, tampouco nossa utopia.

É no exercício do fazer docente que não se restringe ao cumprimento de tarefas sem sentido que, como professores/as, vamos materializando nossos sonhos. É na tensão entre denúncia e anúncio que o novo surge como possibilidade. É o inédito viável que emerge, o ainda não pensado, não experimentado, mas que em resposta às provocações postas pelas situações-limite, que momentaneamente nos paralisam, aponta outro caminho. Como Freire (2001) nos diz: "os insucessos e os sofrimentos fazem parte da busca da eficácia. Não há eficácia que não tropece em momentos de insucesso. É preciso trabalhar o insucesso e convertê-lo em êxito.” (p. 172)

Assim, o ensino vai sendo substituído pelo treinamento, transformando a docência em uma atividade técnica de adestramento - uma vez que deixa de lado a formação para a reflexão em nome do preparo para a execução de tarefas -, objetivando treinar os/as estudantes para realizar os exames externos ou internos, pois se verifica que a avaliação das aprendizagens efetivada no cotidiano escolar acaba por obedecer à lógica de Chronos, com a instituição de semana de provas e aulas de revisão que as antecedem. E enquanto empurramos a pedra da pandemia, neste tempo de espera, muitas perguntas são feitas, mas quase todas com a mesma intencionalidade: foi/foram anos perdidos? $\mathrm{O}$ que aprenderam os/as estudantes? Como avaliar esse/s ano/s? Aprovaremos todos/as? Reprovaremos aqueles/as que não acompanharam o que as escolas entenderam ser a melhor forma de realizar o seu papel?

\footnotetext{
${ }^{2}$ Freire, a partir de Álvaro Vieira Pinto, prevê três estágios para a consciência humana: a intransitividade, quando cada mulher e homem está preocupado exclusivamente, por força das circunstâncias, com a manutenção de sua vida; a transitividade ingênua, quando suas necessidades materiais são minimamente satisfeitas e eles podem debruçar-se sobre as questões do mundo que os cerca, mas ainda sem criticidade; e a transitividade crítica, quando se detêm sobre as questões do mundo reflexivamente.
} 
DOI: $10.12957 /$ teias.2021.62392

É a escola que parece adotar um tempo próprio, desconectado da vida. Somente um tempo sustentado na mera produção nos permite inferir que foram anos "perdidos" - devorados pelo voraz Chronos. A única perda experimentada na pandemia foi a de vidas de pessoas, próximas ou não. Perdas que nos ensinaram muito, certamente. $O$ tempo vivido, padecido, nunca pode ser perdido. Apenas uma lógica pautada pela produtividade pode admitir que o tempo vivido "se perde", uma vez que não haja um produto objetivo, derivado dessa experiência.

Para Freire (2011a), o tempo do vivido é o tempo singular, que se junta a outros tempos e temporalidades para construir uma paciência histórica, possibilitando processos pessoais e sociais de humanização. Há que se enganar Chronos, dando-lhe de comer a pedra de Sísifo. É a sagacidade de Kairós que oportuniza experimentar Aión. Denunciar a educação credencialista neoliberal e anunciar uma educação em que nos façamos mais gente. Contra a homogeneização avidamente procurada pelo capital - que exclui aqueles que "não se enquadram" -, a assunção da heterogeneidade característica da humanidade, concedendo a cada um a oportunidade de se tornar cada vez mais si mesmo:

Freire propõe vencer o endeusamento de uma só temporalidade sugerindo uma interculturalidade sincrônica na ação cultural para a liberdade, a qual as utopias (futuro) sejam o inédito viável presentificado pelo esperançar (presente)em diálogo com as raízes étnico-culturais (passado) vivas em nós. Não há educação freiriana sem despertar em cada um/uma o gosto de temporificar-se no fluxo incessante das urgências e dos apelos da vida pela justiça e pela liberdade. (PASSOS, 2010, p. 391)

Talvez, dando a Chronos a pedra de Sísifo, poderíamos quebrar os relógios que marcam o tempo da História, como Benjamin (1992) pensou, e intervir mais fortemente na realidade como sujeitos históricos e menos intransitivos. Tal tarefa, segundo Freire (1996), poderia gerar mais saberes do que simplesmente adaptar-se ao caminhar cronológico da História. Contudo, não podemos nos conformar só com um outro tempo, pensamos nós, mas, talvez, um outro olhar conseguisse nos fazer enxergar algo diferente; uma faísca ou um lampejo de possibilidade esperançada. Boaventura de Sousa Santos vem ao encontro de Paulo Freire através da proposição de uma Sociologia das Ausências e de uma Sociologia das Emergências. Aquela faz com que "[...] as experiências que já existem mas são invisíveis e não críveis estejam disponíveis" (SANTOS, 2007, p. 32) - o diálogo com as raízes étnico-culturais -, e esta nos permitiria "[...] ampliar o presente e contrair o futuro" (ibidem, p. 38) - o inédito viável presentificado pelo esperançar, num tempo outro, entre Aión e Kairós, elaborando táticas no território de propriedade de Chronos. Há que se afirmar uma epistemologia para além do paradigma de sujeição não refletida e da vassalagem epistemológica a modelos hegemônicos, não raro de natureza colonializante, simplesmente porque "não há alternativa" - o mantra fatalista do neoliberalismo sob o império de Chronos, a serviço da produtividade.

Portanto, o que podemos nós, professores/as? O que poderia Sísifo? Haveria alternativas para nós? Todos os discursos oficiais, alinhados com as demandas do capital, afirmam que são muito poucas. Devemos nos submeter, colaborar e cumprir os programas, aceitar a qualidade que é ratificada pelo IDEB, apoiar as reformas e nos resignar ante a precarização de nosso fazer? "Há que se fazer mais com menos". Fazem-nos pensar que não há alternativa. "Role a pedra", eis o imperativo do tempo da espera...

Sabemos que Sísifo está só, cansado e fragilizado. Entretanto, ele não pode abandonar sua pedra, e tampouco nós, professores/as, abandonaremos as nossas. E, apesar de conhecermos Sísifo como uma figura solitária, ao olharmos bem para sua constante tarefa, inevitavelmente, vemos 
também a nossa. Seria apenas o nosso reflexo em seus olhos ou estaríamos com ele carregando, talvez em vão, a mesma pedra vezes sem conta? Precisamos de menos Chronos e mais Aión e Kairós para que, de dentro de nossa zona de autonomia relativa, possamos estender o presente e comprimir o futuro - as promessas da modernidade, a espera pela pós-pandemia, suspensas no horizonte, são ilusões que nos imobilizam no tempo de Chronos, o tempo da espera. É preciso esperançar para buscar, atrás de cada situação-limite, o inédito viável a ser capturado taticamente.

E vamos seguindo, rolando a pedra, uma pedra de todos os dias, mas não em obediência ao fatalismo neoliberal, e sim por dedicação a um trabalho constante que apresenta sua boniteza justamente por não ter um final como objetivo, mas sua execução como propósito. E tal propósito, pautado por uma educação democrática, por uma escola pública popular, nos encanta e move, levanos ao encontro da esperança de empurrarmos a mesma pedra e que, cada vez, ela possa nos pesar menos. O alívio do peso da pedra não significa o abandono da tarefa, muito menos a fuga da luta. O alívio da pedra pode juntamente vir de outros braços, de outros Sísifos que em seus cotidianos movem a engrenagem rumo à educação que esperamos e à qual temos direito. Contudo, fica uma questão: Estaremos fadados/as a ser sempre Sísifos? Se assim for, o que teria a pedra para nos ensinar? Certamente não apenas exaustão e desesperança. Há algo além do puro ordálio e é exatamente esse algo que não está ainda diante de nossos olhos, mas que nos inspira a cada amanhecer a erguer nossas pedras, renovados em nossas forças.

\title{
INTRANSITIVIDADE, INFÂNCIA E ESPERANÇA - REFLEXOS DE SÍSIFO EM NÓS?
}

\author{
Uma educação pela pedra: por lições; \\ para aprender da pedra, frequentá-la; \\ captar sua voz. inenfática, impessoal \\ (pela de diç̧ão ela começa as aulas). \\ João Cabral de Melo Neto
}

A figura de Sísifo é o reflexo da intransitividade na qual estamos submersos à revelia. Circunscrito a um contexto de extrema opressão, resumido à punição que lhe fora imposta no Hades, a vida de Sísifo era a pedra. Empurrá-la morro acima; vergar sob seu peso; vê-la escapar algumas vezes de suas mãos. Uma terrível educação pela pedra, parafraseando João Cabral de Melo Neto. Mas a pedra, além do simples obstáculo, pode nos ensinar mais do que sua rigidez hierática sugere.

O que teria a ensinar para nós professores/as, a pedra de Sísifo? Minimamente, ela seria nosso árduo, porém amoroso, trabalho de lecionar. Isto porque cotidianamente insistimos e esperançamos na luta pela educação. Lutamos pelo acesso, permanência e sucesso de nossos/as educandos/as das classes populares. Faz parte de nossa premissa observar o brilho no olhar ou oferecer o incentivo necessário para responder questões consideradas "difíceis", por exemplo.

Agimos como Sísifo, sim. Mário Rivero foi feliz em seus versos. Contudo, observar o esforço de Sísifo não nos faz meros espectadores/as de uma situação desesperadora, da qual somos espelhos. Há que se contemplar não apenas o empenho, mas os olhos de Sísifo através de uma outra ótica: a esperança.

Sísifo não se senta sobre a pedra ou se prostra à sua sombra; o filho de Éolo continua a empurrá-la morro acima, vez após vez. A esperança pode mover seus braços e pernas - a pedra há de chegar ao cume -, mas a precariedade de sua situação, enquanto condenado nas paragens do 
tártaro, o mergulha na intransitividade, de modo que ele age sempre da mesma forma, obtendo os mesmos resultados.

Essa intransitividade na qual Sísifo está mergulhado também acomete a nós enquanto professores/as, submetidos tantas vezes a condições precárias de atuação - salas cheias, restrição de material didático, alunos em dramática situação de vulnerabilidade social, escolas em comunidades mergulhadas numa rotina cíclica de violência. Mas ao contrário do que se pensa, a intransitividade não é uma sina inescapável nem exclui a faceta infantil existente em nós ou em nossos/as educandos/as; ou seja, a intransitividade não impede a experiência de Aión - a infância é o outro, o não-eu. Esquecemo-nos dela, muitas vezes. Eis a sisífica ironia da condição docente: esquecido da infância, ou a relegando a um tempo apenas de Chronos, o/a professor/a, sob o peso de sua pedra, perde de vista a esperança e se resigna à espera. Enlutados/as da infância, perdemos o melhor dos mundos, o contato direto com o reino do esperançar - "e se eu fizesse com que as coisas fossem diferentes?" Por isso, Freire (2011) nos convocou a nunca abandonar a infância dentro de nós. Kohan (2007), por sua vez, nos convida a levar a sério a novidade de cada nascimento e impedir que ele encontre seu fim em si mesmo, estendendo o nascer à vida toda e não apenas ao acontecimento biológico do parto (p. 111). O nascimento é o lembrete da renovação da vida e das oportunidades de recomeço.

"Tudo seria perfeito se o homem pudesse fazer as coisas duas vezes", nos diz Benjamin (1992, p. 175) ao citar Goethe. Recomeçar é sempre preciso, mas nós vamos seguindo o fluxo das circunstâncias, esquecidos da infância em nós, desesperançados. Contudo, o que teria o exemplo de Sísifo a nos dizer, caso olhássemos para sua repetição contínua como Kohan nos convida a olhar? Talvez pudéssemos ver a repetição da maneira como as crianças o fazem: cada tentativa é uma novidade, e a próxima vez pode ser diferente. Seria uma lição de esperança? De esperançar no sentido que Freire (2011a) nos ensina?

Não a espera pura e simples ou a repetição do mesmo, cansativa e enfadonha, mas o novo sempre novo, renovado a cada subida por uma nova oportunidade ressignificada na mesma e cansada pedra. Inclusive, o fardo talvez não seja de todo mau; há, no peso da pedra um insofismável vínculo com a realidade concreta que nos cerca (KUNDERA, 2008); o mesmo peso que nos oprime é a âncora que nos prende ao mundo, evitando que nos distanciemos do paradigma social que compartilhamos com nossos/as colegas e estudantes: "O mais pesado dos fardos é, portanto, ao mesmo tempo a imagem da realização vital mais intensa. Quanto mais pesado é o fardo, mais próxima da terra está nossa vida, e mais real e verdadeira ela é." (Idem, p. 11)

Quando olhamos para a sorte de Sísifo, o que vemos é a nós mesmos. No entanto, se pudéssemos observar o esforço de Sísifo sob a ótica de Milan Kundera, nossas pedras cotidianas, talvez pudéssemos ver que as marcas e dores de todos nós, professores/as extenuados/as pelos inúmeros colapsos sanitários, econômicos e sociais que atravessamos nos últimos dois anos, e que acometem cada centímetro da vida dos mais fragilizados socialmente, tem o mérito de nos aproximar da realidade que ansiamos por ver transformada. A dor, se corretamente encarada, evita a intransitividade do desespero ou da espera inócua, no tempo de Chronos, conecta-nos ao mundo tal qual ele é e evita a romantização da realidade. É a pedra como paráclito contra a alienação.

Oxalá encontrássemos nos olhos de Sísifo a esperança fantasiada de sonho, de sonhos possíveis, de diálogo, de revolução e de luta:

Os sonhos são projetos pelos quais se luta. Sua realização não se verifica facilmente, sem obstáculos. Implica, pelo contrário, avanços, recuos, marchas às vezes demoradas. Implica luta. $\mathrm{Na}$ verdade, a transformação do mundo a que o sonho aspira é um ato político e seria uma ingenuidade não reconhecer que os sonhos têm os seus contra-sonhos. (FREIRE, 2000, p. 54) 
DOI: $10.12957 /$ teias.2021.62392

"O sonho de um mundo melhor, nasce das entranhas de seu contrário", nos ensinou Freire (2000). Este seria o papel da educação: para além das condições intransitivas, demonstrar que um mundo diferente é difícil, mas não impossível, e que é necessário esperançar - nem agir cegamente, constrangido pelas exigências da intransitividade, nem esperar passivamente pela melhora das condições objetivas ou aceitar o mundo como dado. Capturar em pleno voo as oportunidades fugazes que surgem nas brechas do poder proprietário (CERTEAU, 2014), construindo possibilidades outras de reescritura da história. Astúcia e esperança. Kairós e Aión.

Justamente por saber que mudar é difícil, mas é possível - colocação que Freire (2000) repete várias vezes na Pedagogia da Indignação, por exemplo - que suspendemos e carregamos a pedra. Vamos munidos de sonhos, de esperanças e de utopias para tentarmos chegar ao cume da montanha, tal qual Sísifo. Talvez esse cume tão almejado não represente o final da luta, mas o esforço diário pela formação ética, estética e política na formação humana. Esse cume pode representar o esforço árduo, mas extremamente necessário. Fica em nós sempre o convite de começar tudo de novo. Não com um "faz de conta que", mas um "fazer sempre de novo" (BENJAMIN, 1992, p. 176).

Fica em nós também a mensagem de Kohan (2017) que diz: "Mestre, longe de ser quem forma a infância, é quem procura manter o aluno nela para que, dessa potência e exposição ao mundo, ele possa tirar toda a força da qual é capaz." Assim, o papel do/a professor/a/ mestre/a, tal como Sísifo no mito, tem o potencial de despertar a força com seu exemplo. Essa mesma força que pensamos vir da adultez, ela vem principalmente da infância da qual urge não nos distanciarmos.

Esse "fazer sempre e de novo" benjaminiano associado à infância é o curso ou a excursão que Barthes (apud KOHAN, 2017) traz e que nos aproxima ainda mais da trajetória ou viagem que Sísifo faz ao tentar alcançar o cume da montanha. Conforme dissemos, Sísifo está condenado, mas não estaríamos nós, professores/as, também enredados na utopia freireana que nos alimenta e nos move diariamente? Alcançar o cume não nos traria a satisfação de uma tarefa pronta, mas tal satisfação talvez estivesse essencialmente atrelada ao vivenciar da experiência do tarefeiro; aquele que não desiste de seu esforço (movimento excursionista) em prol daquilo que acredita.

Esse seria o sentido da palavra "pedagogia", a vida como excursão, o exercício pedagógico como uma excursão infantil (KOHAN, 2017). Os rodopios da criança em torno da mãe podem parecer repetitivos e cansativos aos olhos de quem a observa, mas para a criança constitui uma experiência sempre renovada em cada ida e vinda. Sísifo nutre suas idas e vindas pela obrigação e esperança de alcançar o cume; o/a professor/a provavelmente não enxerga seu esforço diário como enfadonho e repetitivo em sua essência, caso contrário não colocaria nele suas esperanças renovadas em cada ano letivo que se inicia ou cada turma de estudantes que escolhe acolher, compartilhar e trocar conhecimentos.

Talvez faça parte da luta cotidiana essa renovação de forças pela repetição exaustiva da tarefa. Mudar não é fácil, mas é possível, nos diz mais uma vez Freire e no bojo da luta está o esforço, a persistência e a esperança. Conhecemos a educação no Brasil sem esses elementos? Somos capazes de enxergar a nossa prática pedagógica sem eles? Freire sinalizou a dificuldade inerente ao longo de suas obras, mas nos deixou munidos de uma importante arma para que a luta não cessasse por mais difícil que pudesse ser: a esperança. 
DOI: $10.12957 /$ teias.2021.62392

\title{
PALAVRAS INCONCLUSIVAS E POR ISSO, ESPERANÇOSAS
}

\author{
Precisamos de (re)encantarmos o mundo, \\ tomando por empréstimo \\ o olhar das crianças \\ Mia Couto
}

Tomar o Mito de Sísifo para pensar o trabalho do/a professor/a nos coloca diante da certeza do inacabamento desse fazer, como inacabados somos também:

Sabemos que em torno da palavra formação, Building, e portanto, em torno da pedagogia e da reforma, se decide na reflexão filosófica desde Protágoras e Platão, desde Pitágoras, um núcleo essencial. Tem como pressuposto que o espírito dos homens não lhes é dado como preciso, e deve ser re-formado. $\mathrm{O}$ monstro dos filósofos é a infância. Também é cúmplice deles. A infância diz-lhes que o espírito não é dado. Mas que é possível. (LYOTARD apud ARROYO, 2013, p. 40-41)

Um trabalho que não se pauta em resultados, mas em processos. O objetivo não é depositar a pedra, dela desfazer-se, mas movê-la sempre; sempre para cima, sempre em frente, não importa quantas vezes seja necessário (re)movê-la. Sob esta ótica, Sísifo não é um condenado: é um utopista incansável. Sua utopia não se encontra no cumprimento de uma meta, mas em seu eterno (re)fazer. A terrível Síndrome de Burnout, que consome educadores/as em todo o mundo, nasce também da perspectiva de um trabalho sem resultados, cujas metas nos parecem inalcançáveis, levando-nos a crer que nossos melhores esforços são infrutíferos ou insuficientes ${ }^{3}$. Apresentação de resultados mensuráveis em índices dentro de um espaço de tempo delimitado - educadores trabalhando com o faminto Chronos em seus calcanhares.

Um trabalho que depende da reciprocidade dos/as estudantes e do contexto no qual está inserido. A docência, porque comprometida com a educação, é um fazer de processo aberto, inconcluso e por isso, de possível transformação. $\mathrm{O}$ foco no resultado desumaniza o processo, perverte o trabalho docente colocando-o na lógica da produção. A percepção de empurrar a pedra morro acima com o único objetivo de concluir um trabalho, concentrados/as na chegada, nos impede de nos relacionar com o caminho, de observar e nos encantar com o que nunca tínhamos visto antes, ainda que passássemos por este caminho todos os dias, nos mesmos horários. É impossível retomarmos Sísifo como força de resistência contra o tempo de Chronos sem aludirmos à absurdidade de Albert Camus. Para ele, a existência não tem sentido, num mundo em que os/as homens/mulheres têm como horizonte certo apenas a morte. A vida é absurda. Há dois remédios para isso: o suicídio - prova inconteste da vitória do tempo de Chronos sobre nós - ou a aceitação, sem subterfúgios escapistas, da absurdidade da existência, vivendo plenamente a vida absurda - a vitória da tática de Aión e Kairós sobre o desespero. Note que não se fala da vitória dos sujeitos da educação popular sobre a estratégia neoliberal que visa a conformá-los e consumi-los; é, antes, uma vitória do esperançar sobre o desespero:

Deixo Sísifo no sopé da montanha! Sempre se reencontra seu fardo. Mas Sísifo ensina a fidelidade superior que nega os deuses e levanta os rochedos. Ele

\footnotetext{
3 “A Síndrome de Burnout também pode acontecer quando o profissional planeja ou é pautado para objetivos de trabalho muito difíceis, situações em que a pessoa possa achar, por algum motivo, não ter capacidades suficientes para os cumprir". Disponível em: <http://antigo.saude.gov.br/saude-de-a-z/saude-mental/sindrome-de-burnout $>$. Acesso em 11 set. 2021.
} 
também acha que tudo está bem. Esse universo doravante sem senhor não lhe parece nem estéril nem fútil. Cada um dos grãos dessa pedra, cada clarão mineral dessa montanha cheia de noite, só para ele forma um mundo. A própria luta em direção aos cimos é suficiente para preencher um coração humano. É preciso imaginar Sísifo feliz. (CAMUS, s/d, livro digital)

Não se trata de conformação, haja vista que cabe a cada educador/a continuar na labuta de uma educação que defenda como legítima para as classes populares, e não o que se apregoa como uma educação de resultados. Tampouco é mera resignação, haja vista que esperançar é agir em prol de um objetivo, ainda que este objetivo não tenha um termo em horizonte. Convivendo entre as forças de Chronos, Kairós e Aión, seguimos ora na espera, ora com esperança. Esperança que, sustentada pelas táticas de resistência, ao mesmo tempo as possibilita. Afinal, o que nos cabe enquanto educadores/as, senão a esperança da transformação? Voltando à questão que outrora colocamos: $\mathrm{O}$ que fazemos em nossas vidas/docência senão subir pedregulhos cotidianamente? Sísifo enganou a morte e foi condenado por isso. Talvez tenhamos nós também a nossa "condenação": esperançar! Porque esperançamos, resistimos, mesmo quando nos parece não fazer mais sentido. Tomando emprestado o olhar das crianças, aprendemos que não nos cabe "[...] uma educação para a esperança. O papel do educador e da educadora é cuidar para que a esperança não se desvie e não se perca, caindo ou na desesperança ou no desespero. Em sendo um imperativo histórico, a esperança se manifesta na prática.” (STRECK, 2010, p. 161).

Nossas palavras serão sempre inconclusivas, assim como as tarefas e/ou as pedras que cotidianamente carregamos, mas são inconclusivas porque esperançosas e esperançosas porque resistentes. Existe resistência maior que a da pedra? Seguimos Camus quando diz que por vezes nos confundimos com as pedras, somos nós a carregá-las ou somos por elas carregados? Alavancamos a educação com nossas lutas e resistências ou somos por ela encantados, esperançados e inspirados a continuar?

\section{REFERÊNCIAS}

ARROYO, Miguel Gonzales. Ofício de mestre: imagens e autoimagens. 15. ed. Petrópolis: Vozes, 2013.

BENJAMIN, Walter. Sobre Arte, Técnica, Linguagem e Política. Tradução: Maria Luz Moita. Lisboa: Relógio d' Água, 1992.

CAMUS, Albert. O mito de Sísifo: ensaio sobre o absurdo. Exilados dos Livros, s/d, livro digital.

CERTEAU, Michel de. A Invenção do Cotidiano 1: Artes de Fazer. 18. ed. Tradução: Ephraim Ferreira Alves. Petrópolis, RJ: Vozes, 2012.

FREIRE, Paulo. Pedagogia da Autonomia: saberes necessários à prática educativa. 37. ed. São Paulo: Paz e Terra, 1996.

FREIRE, Paulo. Pedagogia da Esperança- Um reencontro com a Pedagogia do Oprimido. Rio de Janeiro: Paz e Terra, 2008.

FREIRE, Paulo. Pedagogia do Oprimido. 50. ed. São Paulo: Paz e Terra, 2011a.

FREIRE, Paulo. Educação como Prática de Liberdade. 14. ed. São Paulo: Paz e Terra, 2011b.

FREIRE, Paulo. Direitos humanos e educaşão libertadora. 2. ed. Rio de Janeiro/São Paulo: Paz e Terra, 2020.

FREIRE, Ana Maria (org.) Pedagogia da Indignação: cartas pedagógicas e outros escritos. São Paulo: Editora UNESP, 2000. 
DOI: $10.12957 /$ teias.2021.62392

FREIRE, Paulo. Pedagogia dos Sonhos Possiveis. São Paulo: Editora UNESP, 2001.

KOHAN, Walter. Infância, estrangeiridade e ignorância: ensaios de Filosofia e Educação. Belo Horizonte: Autêntica, 2007.

KOHAN, Walter Omar. Em defesa de uma defesa: elogio de uma vida feita na escola. In: LARROSA, Jorge (org.) Elogio da Escola. Trad. Fernando Coelho. Belo Horizonte: Autêntica, 2017, p. 65-86.

KUNDERA, Milan. A insustentável leveza do ser. São Paulo: Companhia das Letras, 2008.

PASSOS, Luiz Augusto. Tempo (verbete). In: STRECK, Danilo e outros (org.). Dicionário Paulo Freire. Belo Horizonte: Editora Autêntica, 2010.

VASCONCELOS, Celso dos Santos. Avaliação classificatória e excludente e a inversão fetichizada da função social da escola. In: FERNANDES, Cláudia de Oliveira (org.). Avaliação das aprendizagens: sua relação com o papel social da escola. São Paulo: Cortez, 2014, p. 17-56.

SANTOS, Boaventura de Sousa. Renovar a teoria crítica e reinventar a emancipação social. São Paulo: Boitempo, 2007.

STRECK, Danilo. Esperança (verbete). In: STRECK, Danilo e outros (org.). Dicionário Paulo Freire. Belo Horizonte: Editora Autêntica, 2010.

Submetido em setembro de 2021. Aprovado em outubro de 2021.

\section{Informações do(a)(s) autor(a)(es)}

Aline Praça Bernar

Colégio de Aplicação- Universidade Federal do Rio de Janeiro (UFRJ)

E-mail: alinebernar@yahoo.com.br

ORCID: https://orcid.org/0000-0003-0985-9287

Link Lattes: http://lattes.cnpq.br/5941884191610001

Fabiana Eckhardt

Universidade Católica de Petrópolis (UCP)

E-mail: fa.eckhardt@gmail.com

ORCID: https://orcid.org/0000-0002-7933-6572

Link Lattes: http://lattes.cnpq.br/1885063632387826

Renato Simões Moreira

Universidade Federal Fluminense (UFF)

E-mail: renatosimoesmoreira@hotmail.com.br

ORCID: https://orcid.org/0000-0001-5607-7072

Link Lattes: http://lattes.cnpq.br/1199820820946216 